\title{
PROSTATITAS: DIAGNOSTIKA IR GYDYMAS
}

\author{
Marius Rinkevičius \\ Lietuvos sveikatos mokslu universitetas, Medicinos akademija, Medicinos fakultetas
}

Raktažodžiai: prostata, lètinis prostatitas.

\section{Santrauka}

Lètinis prostatitas - tai vyrų priešinès liaukos uždegimas, smarkiai apsunkinantis gyvenimo kokybę. Šią ligą ypač sunku diagnozuoti daugeliui gydytojų urologų. Tyrimo tikslas - apžvelgti mokslinę literatūrą apie prostatito diagnostiką ir gydymą. Išvados. Lètinis prostatitas yra plačiai paplitusi vyrų liga, reikalinga ypatingų gydančio mediko pastangų. Gydytojams urologams svarbu nustatyti prostatito tipą, nes nuo tipo priklausys tolimesnis paciento tyrimas ir gydymas. Diagnozavus lètinį dubens skausmo sindromą, svarbu suprasti, kad nuolatinè antibiotikoterapija bus neveiksminga, todèl rekomenduojama multimodalinè terapija, atsižvelgiant ị kiekvieno paciento klinikinị fenotipinị profilį.

\section{Ivadas}

Prostatitas - tai vyrų priešinès liaukos uždegimas. Lètinè šios ligos forma ypač apsunkina sergančiųu gyvenimo kokybę. Lètini prostatitą sunku diagnozuoti daugeliui gydytojų. Manoma, kad prostatos uždegimas diagnozuotas 4,5-9 proc. populiacijos, o vyresnio amžiaus pacientams šios ligos pasikartojimo dažnis siekia 50 procentų [1]. Vien Kanadoje kiekvienas urologas konsultuoja per metus apie 262 pacientus, kuriems diagnozuotas lètinis prostatitas [2]. Jungtinèse Amerikos Valstijose per metus reikia daugiau nei 2 milijonu konsultacijų dẻl vyrų priešinès liaukos uždegimo [3].

Tyrimo tikslas - apžvelgti mokslinę literatūrą apie prostatito diagnostiką ir gydymą.

\section{Tyrimo rezultatai ir diskusija}

Klasifikacija. 1995 m. buvo susitarta dèl standartinès šiuolaikinès prostatito klasifikavimo sistemos.

Ūminis bakterinis prostatitas (1 kategorija). Sukelia šlapimo takų infekcijos sukèlèjai, patekę ị prostatos liauką. Būdingi simptomai: šaltkrètis, karščiavimas, skausmingas ir dažnas šlapinimasis. Ūminiam bakteriniam prostatitui reikia skubios medicininès pagalbos.

Lètinis bakterinis prostatitas (2 kategorija). Bakteri- jos prostatos liaukoje sukelia pasikartojančias šlapimo takų infekcijas, kurias sunku gydyti.

Lètinis dubens skausmo sindromas (3 kategorija). Labiausiai paplitęs prostatito tipas, sukeliantis lètinị dubens, tarpvietės ir lytinių organų skausmą. Yra uždegiminis ir neuždegiminis tipai.

Asimptominis uždegiminis prostatitas (4 kategorija). Ši būkle sukelia prostatos uždegimą, bet simptomų nèra [4].

\section{Diagnostika}

Ūminis bakterinis prostatitas (1 kategorija) ir lètinis bakterinis prostatitas (2 kategorija): atlikus šlapimo tyrimą prieš prostatos masažą, randama leukocitų ir bakterijų, tačiau jų gali ir nebūti. Po prostatos masažo visuomet bus randama baltụjų kraujo kūnelių ir bakterijų.

Lètinis dubens skausmo sindromas (3 kategorija): atlikus šlapimo tyrimą, nei leukocitų, nei bakterijų nerandama. Po prostatos masažo ištyrus šlapimą galima aptikti leukocitų, o tai būdinga lètinio dubens skausmo sindromo uždegiminiam tipui.

Asimptominis uždegiminis prostatitas (4 kategorija): diagnozuojamas atsitiktinai, pavyzdžiui, atlikus prostatos biopsiją. Šlapimo tyrime leukocitų ir bakterijų nerandama, bet šlapimą vertinant po prostatos masažo visada randama leukocitų [5].

\section{Gydymas}

Üminis bakterinis prostatitas (1 kategorija). Pradiniam sunkiai sergančių pacientų gydymui rekomenduojama ị veną suleisti dideles baktericidinių antimikrobinių medžiagų dozes, pavyzdžiui, aminoglikozidų kartu su ampicilinu, plataus spektro penicilino kartu su beta laktamazès inhibitoriumi. Pacientai gali būti gydomi geriamuoju fluorochinolonu, jei ligos eiga nèra sunki. Trimetoprimo sulfametoksazolas nerekomenduojamas kaip pirmosios eilès empirinis gydymas, jei atsparumas dažniausiam patogenui $E$. coli yra didesnis nei 10-20 procentu. Gydymo trukmé nuo 2 iki 4 savaičių. Jei pacientui pasireiškia sunkūs obstrukciniai simptomai, rekomenduojama atlikti vieną kateterizaciją. Būtina hospitalizuoti 
pacientus esant ilgai trunkančiam vėmimui, sunkiai dehidratacijai, tachikardijai, tachipnejai, hipotenzijai ir kitiems su urosepsiu susijusiems simptomams.

Lètinis bakterinis prostatitas (2 kategorija). Rekomenduojami fluorochinolonai. Atlikti tyrimai patvirtino, kad tai efektyvus pirmos eilès gydymas, kurio trukmè nuo 4 iki 6 savaičių. Jei nustatomas patogeno atsparumas fluorochinolonams, galima apsvarstyti gydymą trimetoprimo sulfametoksazoliu. Tada gydymo trukmè turètų būti nuo 8 iki 12 savaičių. Norint sumažinti recidyvų tikimybę, prie antimikrobinių galima pridèti alfa blokatorius [6].

Lètinis dubens skausmo sindromas (3 kategorija). Nerekomenduojamas nuolatinis gydymas empirinių antibiotiku kursais. Monoterapija retai duoda teigiamų gydymo rezultatų dèl lètinio dubens skausmo sindromo multietiologijos. Šiuo metu labiausiai rekomenduojamas gydymas - multimodaline terapija, atsižvelgiant ị kiekvieno paciento klinikinị fenotipini profili. Ši gydymo būdą sudaro a blokatoriai, antimikrobiniai ir uždegimo slopinamieji vaistai, neuroleptikai, antidepresantai, fizioterapija, akupunktūra, ekstrakorporinè smūginių bangų terapija ir kiti skausmo malšinimo metodai. Studijos parodè, kad ekstrakorporinè smūginių bangų terapija gali padidinti bendrą klinikinį veiksmingumą ir pagerinti lètinio prostatito simptomus, gydant ši sindromą. Psichologinès konsultacijos galètų būti naudingos pacientams, kuriems patvirtinta lètinio prostatito 3 kategorija $[7,8]$.

Asimptominis uždegiminis prostatitas (4 kategorija). Šis tipas asimptomis, todèl gydymas neindikuotinas, tačiau padidèjęs prostatos specifinis antigenas, nevaisingumas ir planuojama prostatos biopsija yra galimos indikacijos pradèti gydymą antimikrobiniais vaistais [6].

\section{Išvados}

1. Lètinis prostatitas yra plačiai paplitusi vyrų liga, reikalinga ypatingų mediko pastangų, gydant pacientą.

2. Gydytojams urologams ypač svarbu nustatyti prostatito tipą, nes nuo tipo priklausys tolimesnis paciento ištyrimas bei gydymas.

3. Diagnozavus lètinị dubens skausmo sindromą, svarbu suprasti, kad nuolatiné antibiotikoterapija bus neveiksminga, todèl rekomenduojama multimodalinè terapija, atsižvelgiant i kiekvieno paciento klinikinị fenotipinị profilị.

\section{Literatūra}

1. Vaidyanathan R, Mishra VC. Chronic prostatitis: Current concepts. Indian Journal Urology 2008;24(1):22-27.

https://doi.org/10.4103/0970-1591.38598
2. Collins MM, Stafford RS, O'Leary MP, Barry MJ. How common is prostatitis? A national survey of physician visits. J Urol 1998;159:1224-8. https://doi.org/10.1016/S0022-5347(01)63564-X

3. Nickel JC, Nigro M, Valiquette L, Anderson P, Patrick A, Mahoney J. Diagnosis and treatment of prostatitis in Canada. Urology 1998;1998:797-802. https://doi.org/10.1016/S0090-4295(98)00297-0

4. Sung YH, Jung JH, Ryang SH, Kim SJ, Kim KJ. Clinical significance of national institutes of health classification in patients with chronic prostatitis/chronic pelvic pain syndrome. Korean J Urol 2014;55(4):276-80.

https://doi.org/10.4111/kju.2014.55.4.276

5. Dickson G. Prostatitis--diagnosis and treatment. Aust Fam Physician 2013;42(4):216-9.

6. Nickel JC. Prostatitis. Can Urol Assoc J 2011;5(5): 306-315. https://doi.org/10.5489/cuaj.686

7. Zhang J, Liang C, Shang X, Li H. Chronic Prostatitis/Chronic Pelvic Pain Syndrome: A Disease or Symptom? Current Perspectives on Diagnosis, Treatment, and Prognosis. Am J Mens Health 2020;14(1):1557988320903200.

8. Liao B, Mou XX, Liu JB, Wu T, Cui S. [Extracorporeal shock wave therapy for chronic prostatitis / chronic pelvic pain syndrome: A meta-analysis]. Zhonghua Nan Ke Xue 2019;25(10):914-922.

\section{PROSTATITIS: DIAGNOSTIC AND TREATMENT M. Rinkevičius}

Keywords: prostate, chronic prostatitis.

Summary

Chronic prostatitis is an inflammation of a man's prostate gland that is severely aggravating quality of life for men. This disease is especially difficult to diagnose for many urologists.

The aim of the study was to review the scientific literature about prostatitis diagnostic and treatment. Conclusions - chronic prostatitis is a widespread disease among men that requires special medical effort. It is especially important for urologists to determine the type of prostatitis. When diagnosing chronic pelvic pain syndrome, it is important to understand that antibiotic therapy will be ineffective, and therefore multimodal therapy is recommended for each patient.

Correspondence to: mariusdvynys@gmail.com

Gauta 2021-09-27 